\title{
The Economy of Scandinavian-American Exchange: Donations and Scholarships in the American-Scandinavian Foundation, 1912-1995
}

\author{
Christin Mays \\ Andreas Akerlund
}

\begin{abstract}
The importance of philanthropy for academic exchange cannot be overestimated. Especially in the first half of the twentieth century, scholarships for academic exchange originated from the private sector instead of the state. But what is the relationship between academic exchange and the donations which finance scholarships? How can specific donations and the restrictions placed on them change the flow of exchange? This article investigates donation and scholarship praxis within the American-Scandinavian Foundation (ASF) from 1912-1995, a philanthropic organisation devoted to academic exchange between Scandinavia and the United States. The period, 1912-1944, is characterised by various small donations and few scholarships to mostly American fellows. The second period, 1945-1995, represents an era of economic growth created from a surge in large, restricted donations invested in scholarship funds. This led to an increased number of scholarships to a more geographically diverse population.
\end{abstract}

Keywords

philanthropy, private foundations, American-Scandinavian exchange, scholarships

\section{Introduction}

The importance of philanthropy for academic exchange cannot be overestimated. Scholarships for study and research abroad during the first half of the twentieth century were first and foremost awarded by philanthropic organisations, rather than state authorities. Even with the growing influence of state organisations after the Second World War, philanthropy has continued to play an important role in exchange. However, their work is seldom investigated in detail. There is, for instance, a general lack of research into the impact of philanthropy on Swedish research although an estimated 8-10 per cent of the research funding at Swedish universities in 2001 came from foundations in Sweden or abroad. ${ }^{1}$ Furthermore, though there is a lack of historical estimations, it is probable that the importance of philanthropy for higher education and research was even higher before the expansion of state financing. In

1 Hans Sjögren, "Svenska stiftelser," in Sista fracken inga fickor har: Filantropi och ekonomisk tillväxt, ed. Pontus Braunerhjelm and Göran Skogh (Stockholm: SNS Förlag, 2004), 35-36.

Christin Mays is a Doctoral Student at the Department of Education, Uppsala University, Sweden. Email: christin.mays@edu.uu.se

Andreas Akerlund, PhD, is a Researcher in History at the Department of History, Uppsala University, Sweden.

Email:andreas.akerlund@hist.uu.se 
this article we will focus on the funding of academic exchange, instead of the funding of research projects or infrastructure.

Philanthropic organisations are an interesting study object as they represent a different motivation for funding exchange than that of the state. Contrary to a state scholarship system - as described in the article on exchange funding of the Swedish Institute in this journal issue - funded money is not as flexible. Donations are normally restricted through the will or rules set up by the founder or donors, which are difficult, if not impossible, to change. ${ }^{2}$ Many philanthropic organisations also have other limitations to their work. They might fund exchanges for only a certain level of student or researcher; a particular subject, such as economy or biomedicine; or only work with a limited geographical area. The latter is the case with the American-Scandinavian Foundation which is investigated in this article.

The flipside of these limits is that one organisation may have a relatively high level of importance as a funder within its area of specialisation. ${ }^{3}$ Contrary to state scholarship systems, which are used as tools within public diplomacy for creation of goodwill or as a part of international development assistance, philanthropic organisations can be viewed as more stable in their missions. As shown in the other article on exchange in this special issue, there is historical variation in state-sponsored scholarships, as these are normally thought to work separately for the creation of goodwill, for knowledge transfer within development assistance, for the internationalisation of higher education and research, or for the establishment of international contacts important for trade and economic growth. ${ }^{4}$ Although the use of donations or endowments to philanthropic organisations is restricted by donors or other regulations, there is often enough maneuverability within the board of trustees during times of change. However, contrary to a state-funded, normally tax-funded, program, scholarship funding through a private organisation without a perpetual endowment is more vulnerable to shifts in general economic development, as the economic stability of this type of organisation depends on donations.

The recognition of this fact inevitably directs our interest toward life inside philanthropic organisations, towards the donors and creators of these institutions and their legacy and towards the praxis of the boards of trustees as interpreters of this legacy. How do private donations to philanthropic organisations create scholarships and what impact do these have on the international flow of students and researchers? Is it possible to identify patterns in donation praxis and scholarship funding over time? What have shifts in the economic history of these donations meant for international mobility through a certain organisation? In the present article, the internal economy of the American-Scandinavian Foundation (ASF) is investigated in a long-term perspective. The main aim is to show how the available assets through

2 Waldemar A. Nielsen, Inside American Philanthropy: The Dramas of Donorship (Norman: University of Oklahoma Press, 1996), 10.

3 In Sweden, the research foundations of the Swedish bank Handelsbanken, which funded a large part of economic research in Sweden, serve as an example as compared to the state-run Swedish Research Council or the Riksbankens Jubileumsfond for Humanities and Social Sciences; Lars Engwall, "Stiftelsernas fördelning av forskningsmedel," in Femtio år av forskningsfinansiering: Jan Wallanders och Tom Hedelius stiftelse, Tore Browalds stiftelse, 1961-2011, ed. Bo Damberg and Jonas Rehnberg, 46-51 (Stockholm: Informationsförlaget, 2011).

4 Åkerlund's article in this issue. 
donations and endowments have changed from the establishment of the foundation's scholarship program in 1912 to 1995, and how these changes have affected the awarding of scholarships.

\section{American-Scandinavian Foundation in context: The roles of large and small philanthropy}

In order to grasp how the American-Scandinavian Foundation fits into the historical picture of United States philanthropy, it is important to shortly contextualise the role of both large and small philanthropic organisations in international higher education and research in the twentieth century.

The early twentieth century saw the rise of big philanthropy in the United States in the form of private foundations. The beginning of this rise was marked by the creation of the Carnegie Corporation of New York (1911) and the Rockefeller Foundation (1913), and later the Ford Foundation (1936). These so-called "Big 3" constituted some of the first large-scale, perpetual private foundations in the United States. Established on the premise of paying forward the extreme wealth gained by their respective donors, founders outfitted these foundations with large endowments as well as grand and often abstract goals. ${ }^{5}$ For the Carnegie and Rockefeller foundations, these goals included promoting "the well-being of humanity" and "the advancement and diffusion of knowledge and understanding" respectively, which were operationalised through various concrete endeavors. ${ }^{6}$ An important part of these endeavors were contributions to higher education and research. Since many private foundations, especially the "Big 3," were general purpose, grant-making foundations, their primary way of contributing to the field of higher education and research was through the making of grants from their endowments to universities, research institutes, and other organisations for the creation of infrastructure and in smaller part for the granting of individual scholarships. ${ }^{7}$

Though, the "Big 3 " were among only a few private foundations which granted a significant portion to higher education and research in the international arena. ${ }^{8}$ In fact, American foundations created before 1950 are cited to spend 12.4 per cent of their annual budget on overseas giving. ${ }^{9}$ The influence of these grants in Europe can be seen in the areas of medicine, natural sciences, social sciences, public health, among others. ${ }^{10}$ In Sweden, the influence of Rockefeller grants on medical research

5 Nielsen (1996), 10-19.

6 Waldemar A. Nielsen, The Big Foundations (New York: Columbia University Press, 1972), 35, 50; Merle Curti, American Philanthropy Abroad (New Brunswick: Rutgers University Press, 1963): 175, 188-89.

7 Christian Helgesson, "Donationer i Sverige, filantropi i USA," in Sista fracken inga fickor har: Filantropi och ekonomisk tillväxt, ed. Pontus Braunerhjelm and Göran Skogh (Stockholm: SNS Förlag, 2004), 147.

8 Nielsen (1972), 274-76; Helgesson (2004), 153.

9 Peter Frumkin, "American Foundations and Overseas Funding: New Challenges in the Era of Globalization," in Globalization, Philanthropy, and Civil Society: Toward a New Political Culture in the Twenty-First Century, ed. Soma Hewa and Darwin H. Stapleton (London: Springer Science, 2005): 101.

10 Giuliana Gemelli, ed. American Foundations and Large-Scale Research: Construction and Transfer of Knowledge (Bologna: CLUEB, 2001); John Krige and Helke Rausch, eds., American Foundations and the Coproduction of World Order in the Twentieth Century (Göttingen: Vandenhoeck \& Ruprecht, 2012). 
at the Karolinska Institute in Stockholm has also been documented. ${ }^{11}$ In this way, private foundations were the forerunners to governmental entities in the United States and Europe, which largely focused their international investment on relief and humanitarian aid until after the Second World War. ${ }^{12}$

Parallel to the investment of large foundations in higher education and research were smaller philanthropic organisations, often national or regional in character, more limited in their means and their foci. Since many of these organisations could not rely on perpetual endowments to permanently fund operations, these smaller organisations worked on a more personal level to supplement their endowments by fundraising and utilising grants made from educational institutions, organisations, businesses, and government entities. As a part of operationalising their goals, large private foundations also made grants to smaller philanthropic organisations. ${ }^{13}$ This is a tendency which continues to the present day, as larger foundations continue to use the mission of their founders and their perpetual funds to guide their diverse operations while smaller organisations engage more personally with their unique missions through attracting and utilising donations.

In essence, while large philanthropic foundations focus on the big picture of higher education and research abroad by investing in large-scale projects, infrastructure and other organisations, smaller organisations focus on the day-to-day operationalisation of their own donations and grants made to them. This article focuses on the ASF, one smaller organisation in the United States. Though literature on the ASF is generally confined to self-published overviews of their founding and activities, there is preliminary research which has cited the ASF as being an integral part of the history of United States philanthropy in the role of funding international exchange. What follows is a short overview of the organisation as well as research relating to the role of the ASF in Scandinavian and American academic exchange.

The mission of this New York-based organisation, established in 1911 by the wealthy Danish-American industrialist, Niels Poulson, was to build cultural bridges through educational exchanges between the United States and Scandinavia. In the first thirty years, this meant exchange between Denmark, Norway and Sweden, and the United States, and in later years exchanges were also extended to Finland and Iceland. This exchange, named the Fellowship Program, ran parallel to the ASF's other activities of publishing and translating literature, arranging cultural events and lecture tours, and running their own Bureau of Information. Additionally, the ASF opened the William Henry Schofield Memorial Library in 1929 to provide a place for students, teachers, and researchers to access literature on Scandinavia, and in 1950 they opened the ASF Music Center to encourage American musicians, conductors, and record manufacturers to engage with Scandinavian music and to bring Scandinavian composers and performing artists to the United States. ${ }^{14}$

What set this organisation apart in the early twentieth century was its uniquely

11 Olof Ljungström, Ämnessprängarna: Karolinska Institutet och Rockefeller Foundation 1930-1945 (Stockholm: Karolinska Institutet University Press, 2010).

12 Curti (1963), 175; Frumkin (2005), 99-105.

13 Nielsen (1972), 26-27; Helgesson (2004), 147.

14 Erik J. Friis, The American-Scandinavian Foundation 1910-1960: A Brief History (New York: The American-Scandinavian Foundation, 1961). 
international focus. Merle Curti stresses that the ASF paved the way for the creation of later organisations focused on international academic exchanges including the Netherlands-America Foundation and the Carl Schurz Memorial Foundation. ${ }^{15}$ Preliminary research on the ASF by Dag Blanck also asserts that this organisation has played an important role in shaping the relations between Scandinavia and the United States in the early twentieth century, through the facilitation of cross-cultural contact and influence during academic exchanges. The ASF has provided a conduit for those with Scandinavian backgrounds and those interested in Scandinavian languages, culture, and history to participate in the organisation, whether it be through donating time or money, working as a trustee, or participating in academic exchange or the other activities of the ASF. ${ }^{16}$ This Scandinavian cultural element, which remains a centerpiece of the organisation, has dictated not only the mission of the ASF but the donations to the organisation throughout its history.

Although there have been no long-term studies on the scholarship operations of the ASF in particular, a pilot study was conducted by Andreas Melldahl on the fellows of ASF's cooperating organisation in Sweden, the Sweden-America Foundation (Sverige-Amerika stiftelsen), from 1919-2006. In this report, Melldahl argues that the academic interests of fellows are often connected to economic interests of the nation as board members tend to favor fields deemed economically important within a specific historical context. ${ }^{17}$ Melldahl does not directly discuss the donations and funding behind these cycles, but his results show that there is generally flexibility within the Sweden-America Foundation which allows it to recommend scholars and grant scholarships that respond to the perceived economic interests of the nation. What is missing in his report and what this article investigates are the economic frames and limits created by donations and endowments.

\section{Sources and methods}

The American-Scandinavian Foundation is an excellent study object for the economic development of a small philanthropic organisation focused on international academic exchange. Established in 1911, it has an unbroken history long enough to permit long-term investigations, but its limited size makes it possible to grasp its trajectory within the limited frame of an article. The time period covered in this article extends from 1912-1995, where 1912 is the first year of scholarship operations and 1995 is the last year for which detailed economic data is available.

Two main sources are used for this article, financial statements in the ASF Annual Reports from 1912-1995 and the ASF Directory of Fellows, 1912-1997. Additionally, a database of ASF scholarship holders compiled from the index card system located at ASF headquarters in New York and literature published by the organisation has been utilised to verify and complement information from the above sources. The ASF Annual Reports are located at Carolina Rediviva at Uppsala University and the

15 Curti (1963), 307.

16 Dag Blanck, "Scholars Across the Seas: The American-Scandinavian Foundation and the Sweden-America Foundation in the Transatlantic Exchange of Knowledge," American Studies in Scandinavia 40 no. 1-2 (2008), 112-14.

17 Andreas Melldahl, Västerled tur och retur del 1: Utbildning och ekonomi: En ekonomiskhistorisk studie av Sverige-Amerika Stiftelsens stipendieverksamhet 1919-2006 (Uppsala: SEC Research Reports no. 44, 2008) 
National Library of Sweden in Stockholm, ${ }^{18}$ while the Directory of Fellows has been sourced from the ASF headquarters in New York.

Financial statements in the annual reports are used to trace assets, donations, grants and funds, and scholarship expenditures of the organisation. Fellowships and scholarship expenditures in 1912-1995 have been used to create Figure 1, while grants and funds established in 1945-1980 have been charted in Table 1. Figure 2 shows the total scholarship holders separated by country in 1912-1995.

As the annual reports from 1919, 1953 and 1967-1969 are missing, financial information from these years has been calculated based on yearly scholarship expenditures preceding and following the missing years. In the financial statements of 1936-1940, 1947-1952 and 1954-1962, scholarship expenditures are combined with grants or with trainee administration costs, so scholarship expenditures have instead been taken from the table of total scholarship expenditures from 19471952 recorded in the 1952 annual report; calculated manually for 1936-1940 and 1954-1959; while expenditures for 1960-1962 have been calculated using the same method as data for missing years. In order to remain consistent for all missing data in 1919, 1953, 1960-1962 and 1967-1969, expenditures for missing years are calculated by dividing the total scholarship expenditures by the number of fellows for three years prior to and after the missing year(s). This amount is then multiplied by the number of fellowships for each of the missing years.

In order to trace only the scholarships financed by the ASF, all funding not handled by the treasurer - i.e. any funds given directly to fellows, trainees, or honorary fellows via cooperating organisations, universities, or businesses - has not been included in the calculations of scholarship expenditures. The only exception to this rule is the support through project grants made by private foundations, as these were often woven into the operating budget of the ASF. Because of the length of the investigated time period, the financial statements have changed several times and contain varying levels of detail, which has made the task of determining the exact amount spent specifically on fellowships difficult. Therefore, it is possible that the scholarship expenditures for some years include administrative costs. For the years 1985-1995, administration costs were clearly included in the scholarship expenditures, so they have been removed by calculating the average percentage of administration costs from the years 1970-1984. The totals for scholarship expenditures for missing years as well as for years with included administration costs, grants, and trainee costs are therefore our own calculations and may constitute a slight over/ under-representation of actual scholarship expenditures. Lastly, all scholarship expenditures from 1912-1995 have been adjusted to the price level of 2013 using the United States Consumer Price Index. ${ }^{19}$

Since what will be mapped in this article are the donations and funds given to the ASF as well as the money spent on scholarships, specifically fellowships, terminological clearance is required. There are various kinds of donations which were made to the American-Scandinavian Foundation. The most important distinction is between private donations used for singular or time-limited funding and large bequests or

18 Location of annual reports from specific years can be found in the References.

19 Bureau of Labor Statistics, "Consumer Price Index," United States Department of Labor, http:// www.bls.gov/cpi/. 
endowments used for the creation of perpetual funds. The first type of donation was a small private donation. Donations of this kind were generally given in the form of cash or check and were used immediately to fund specific fellows or within a pre-determined time frame. The second type of donation is a group donation or fundraiser donation made also in the form of cash or check. These were used to create time-limited programs or to create or add to existing funds. The third and fourth types are small and large private bequests or endowments. These were generally given on behalf of a death or in memoriam and were either used in the short-term or to create perpetual funds.

All four of these donation types carried restrictions based on the interest and will of the donor, whether it was for a particular person, within a certain time, or for a specific geographical or academic area. In the case of the ASF, the most common restriction was based on geographical origin or background of particular donors. In the case of donations or bequests for perpetual use, donors also placed specific restrictions on how bequests were to be utilised. Some donors also placed specific limits on the percentage of income which could be used for administration and other related costs, while other donors placed time-limits on use. It was then the task of the Board of Trustees to use the donations or funds available in a certain year to award merit-based fellowships, which met the restrictions placed upon them.

It should be noted that exchange as understood and carried out by the ASF was not based on reciprocity, as discussed in the article on the Swedish Institute in this issue. As such, ASF did not conduct one-to-one exchanges, or create formal bilateral programs - common through state organisations and universities. Instead, the numbers of scholars were determined by the funds available to the ASF in any given year. There were three main programs: for trainees, or those traveling for job training; fellows, or those traveling for study or research; and honorary fellows, or those traveling for teaching or research. Trainees and honorary fellows were generally financed through other organisations, universities or businesses, while the ASF provided contacts and administrated their travels in the United States. Fellows, on the other hand, needed to be vetted and approved by the ASF board of trustees, or the boards of cooperating organisations in Scandinavia, in order to receive scholarships from the ASF. Therefore, fellows are the focus of this article - as they are most closely related to the economic assets of the organisation.

Figure 1 is an overview of scholarship expenditures and fellowships for the period 1912-1995. This figure clearly shows that the available funds as well as the number of awarded scholarships have varied a great deal over the years. As can be seen by this figure, real increases in the level of fellowship expenditures and fellowships were not seen until the mid-1950s. From this point, there was a nearly steady increase in expenditures and fellowships into the early 1990s. Beginning in the 1950s, there was also a large increase in the numbers of fellows from the Scandinavian countries, shaped by changed donation patterns arising in the 1940s. Therefore, a chronological and a thematic division will be utilised in this article. The chronological division will span from 1912-1944 and 1945-1995. The period after the Second World War will be addressed in two ways: firstly, through the changing economic circumstances of the organisation and secondly, through the ways in which this funding affected the fellowship awards. 
Figure 1: ASF scholarship expenditures and fellows 1912-1995

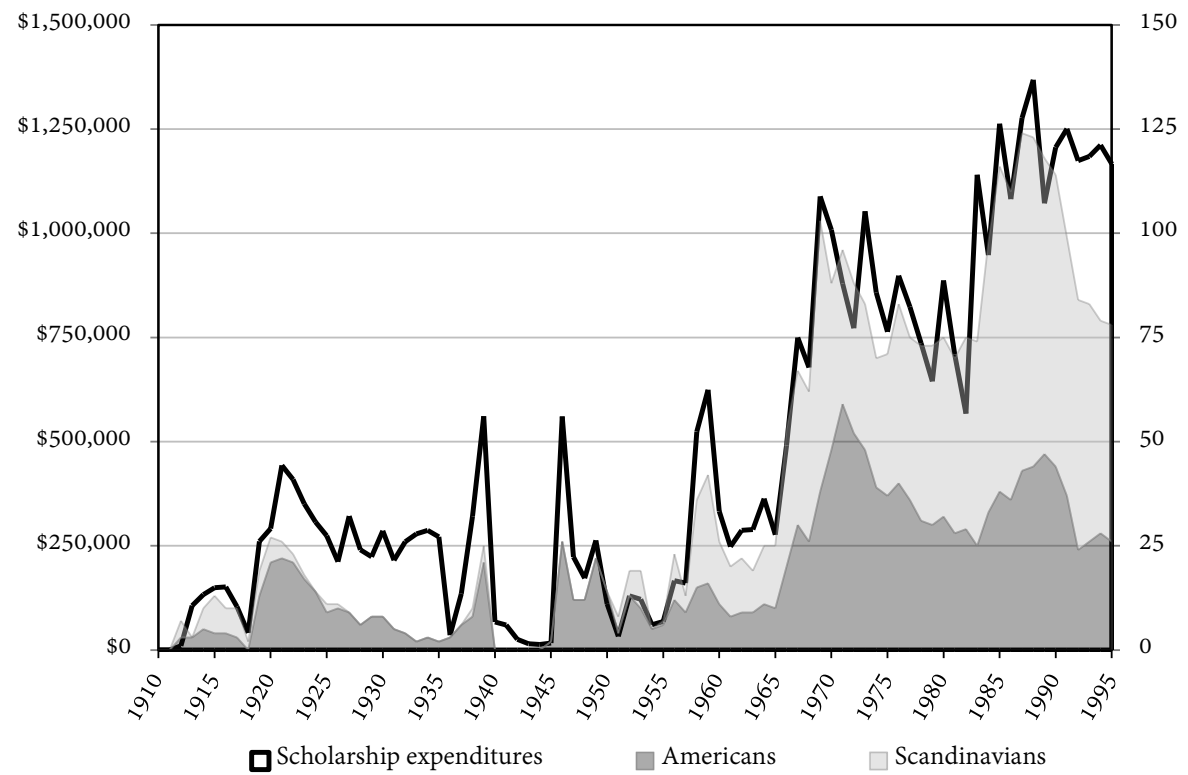

Sources: ASF Annual Reports 1912-95 and ASF Directory of Fellows 1912-97

\section{2-1944: Orientation in the international arena}

The first thirty years of the ASF fellowship can be understood by the personal nature of donations. In these early years, there were two main sources of funding: interest income from the endowment of founder Niels Poulson and private donations for scholarships by private persons. From 1912-1928, much of the core scholarships were funded through the income of the Niels Poulson endowment, while additional scholarships were made possible through donations by private persons with personal ties to the organisation, originating primarily from the United States but also from Scandinavia.

The first part of this period, leading up to the First World War can be seen as a period of orientation for the ASF within the organisational environment of the United States and Scandinavia. In 1913, ASF had officially acquired all of the Niels Poulson endowment bequeathed to the organisation upon his death, which totaled approximately $\$ 500,000$ of bonds and real estate formerly owned by Poulson's company, Hecla Iron Works. Interest income from the bonds and mortgages on real estate was estimated at $\$ 20,000$ per year, which would be used for operating expenses, including administration, publishing, and educational exchange. The real estate, an estimated value of $\$ 100,000$, was to be sold off to add to the principal of the endowment. ${ }^{20}$

These years were also utilised for creating contacts, establishing a solid board of trustees and attracting scholars. This also meant establishing advisory committees

20 American-Scandinavian Foundation 1913 Annual Report, December 31, 1917: 6-8. From herein all annual reports will be notated as ASF AR 19XX, page number. 
in Denmark, Norway, and Sweden - initially appointed by the respective Foreign Ministers - to nominate candidates for scholarships to the United States. ${ }^{21}$ Later, these committees were established as independent cooperating organisations in each of the Scandinavian countries: the Denmark-America Society in 1914, the Norway-America Foundation in 1919, and the Sweden-America Foundation in 1919. These organisations can be seen as complementary to the ASF; they sought their own donations and created their own scholarships, but also recommended Scandinavian fellows for ASF scholarships. ${ }^{22}$ In addition, the ASF also cooperated with universities, which allowed for scholars to receive reduced tuition or grants directly from the universities even if they were not officially financed through the ASF. ${ }^{23}$

During the First World War, there was no real growth in fellowship operations due to the war. In 1919, however, this quickly changed through help from the business communities in Scandinavia and the United States. A group donation by more than 40 private individuals, including bankers, merchants, educators, and industrialists from both sides of the Atlantic, made the first time-limited exchange program possible. The "Five-year Forty-Fellowship exchange" program ran from 1920-25 between Sweden, Denmark, Norway and the United States. Twenty Scandinavians were officially financed through their respective cooperating organisations while twenty Americans were financed through the ASF. Every year for five years, twenty American, ten Swedish, five Danish and five Norwegian fellows were awarded scholarships of $\$ 1000$ each for study or research abroad. ${ }^{24}$ This division of labour between the ASF and its cooperating organs in Scandinavia was to a large extent upheld during the period until the Second World War. This meant that the funds raised by the ASF were primarily used for the financing American scholars, 79 per cent of ASF fellows in this period originating from the United States. ${ }^{25}$

Before the Second World War, program directives like the one described above were rare, and private donations in the form of scholarships were more popular. These scholarships often came directly from ASF trustees to support specific persons, which made these donations both more flexible and more restricted. For example, in 1920 a special fellowship of $\$ 1000$ was awarded to American poet Robert Hillyer for travel to Denmark. This fellowship was made possible through the donation of funds by ASF trustee Henry Goddard Leach. ${ }^{26}$ It was also common for individuals to sponsor specific scholarships for a certain academic subject or geographic area; in the mid-1920s, for instance, there were specific scholarships donated by residents in Gothenburg and Stockholm for Swedish students studying in the United States. These scholarships were administrated by cooperating organisations in Scandinavia, in this case the Sweden-America Foundation in Stockholm, Sweden. ${ }^{27}$

As the ASF attempted to grow, it was increasingly constrained by its small opera-

21 Friis (1961), 29.

22 Blanck (2008), 111-12.

23 ASF AR 1920, 2-3.

24 ASF AR 1920, 20-21; 1923, 3; Friis (1961), 34.

25 Calculated from the 295 fellowships (234 American, 61 Scandinavian) awarded in 1912-44 as listed in the American-Scandinavian Foundation, Directory of Fellows 1912-1997 (New York: American-Scandinavian Foundation, 1998).

26 ASF AR 1920, 5.

27 ASF AR 1926, 26. 
ting budget which could not exceed the interest income of the Poulson endowment. Therefore, starting in 1915, the organisation called for supporters to become Life Associates of the organisation at the one-time cost of $\$ 200$. The ASF had previously used annual dues, or associates dues, to support publications, but they wanted to expand this call so that life associate money could be added to the endowment and therefore to the interest income. In return, Life Associates would receive all publications printed under the auspices of the ASF. By 1923, this call was expanded to include the levels of Patron $(\$ 1000)$, Donor $(\$ 5,000)$, and Benefactor $(\$ 25,000)$. By 1926, there were 65 Life Associates, consisting mostly of Scandinavian-Americans citizens with Scandinavian roots. Several would later bequest large sums to the organisation, including John G. Bergquist, Winnifred Thord-Gray and Frederick Schaefer. ${ }^{28}$

In 1926, Hecla Iron Works fell into financial difficulty and could no longer make payments to the principal of the bonds given to the ASF through bequest in 1913. Although these bonds were set to mature in 1924, ASF agreed to continue holding the bonds for an additional five years. But in June 1926, when Hecla Iron Works could no longer make payments, a two-year process of selling the assets of the company began, so the ASF could finally be in full control of their endowment. Because of the length of this process, and the additional costs associated with the sale and taxation of this property, ASF was deprived of interest income for two years.

Consequently, exchange in 1926 and 1927 was supported mainly through small private donations as well as grants from private foundations. Grants from the Carnegie Corporation and the Laura Spelman Rockefeller Memorial marked the first organised cooperation with large private foundations. By 1928, the majority of Hecla Iron Works property had been sold, and the ASF could again rely on pre-determined holdings in addition to interest income and mortgages to fund operations. ${ }^{29}$ But this victory was short-lived. As the Great Depression swept through the United States, the newly-freed holdings of the ASF depreciated, leaving less income to fund operations, and especially fellowships in the 1930s. In 1929, the ASF held over \$540,000 in assets; by the end of 1937 , they held approximately $\$ 370,000$ in assets. ${ }^{30}$ As a consequence, during the 1930 s a call for supporters to endow funds for fellowships was repeated in every annual report. ${ }^{31}$

This call was finally met in 1939 in memoriam of John G. Bergquist, former vice president and trustee of the organisation. Bergquist's wife, Mrs. Grace Cummings Bergquist, wrote a $\$ 25,000$ check to the organisation on behalf of her late husband. At the time, this was the largest donation since the original contribution of Niels Poulson. According to Grace Cummings-Bergquist, the bequest would be designated "to establish a perpetual Scholarship Endowment whereby an American student appointed by the ASF may carry on his or her advanced studies in Chemistry in Sweden." ${ }^{32}$ In 1944, the second donation designated for endowment was made. This $\$ 25,000$ was given by Hans Christian Sonne, treasurer of the ASF and was to be used

28 ASF AR 1915, 12; 1926, 14-15.

29 ASF AR 1927, 13-15; 1928, 3-5.

30 ASF AR 1929, 14-15; 1937, 14-15.

31 ASF AR 1929, 10.

32 ASF AR 1938, 7. 
to send American fellows to Denmark and Norway. ${ }^{33}$ These endowments would signal the beginning of contributions restricted for capital funds flowing through the organisation, which utilised investment income to fund scholarships.

\section{5-1995: Growth in the system}

After the Second World War, the American-Scandinavian Foundation achieved economic stability and embarked on a road of constant expansion. The number of funds consistently grew in 1945-1995 through group donations and fundraising, private bequests, and organisational grants. This made it possible to award more scholarships on a regular basis, which generated a steady increase in fellows. Moreover, the restrictions attached to funds by the donors also meant a larger variety in origin of the fellows as well as their areas of study or research. In order to address both of these phenomena, the first section will trace the chronology of funding while the second section will discuss the composition of fellows.

\section{A steady flow of donations}

The path to economic stability and growth which began in 1939 continued in 1945 when the first post-WWII donation was made by the American Friends of Norway, a New York-based organisation working for Norwegian interests. Their \$50,000 donation was to become the King Haakon's Birthday Fund, designated for Norwegian students to study in the United States. ${ }^{34}$ In the following 10 years, no additional donations of this magnitude were received, but time-limited grants maintained pre-WWII levels of fellowships, which included the Gustav V Fellowships from the Swedish government.

The Gustav V fellowships resulted from an unanticipated surplus of approximately $\$ 36,000$ donated by the Swedish state to the Swedish Embassy in Washington DC after the Second World War. The surplus was created from the so-called coffee fund, organised by the Swedish consulate in New York for the transportation of private cargo packages, most commonly coffee, from Americans to relatives and friends in Sweden during the war. The extra funds were able to generate a total of 24 fellowships of $\$ 1,500-\$ 2,000$ for American fellows with a working knowledge of Swedish to study literature, history, art, government, social sciences, and economics in Sweden. ${ }^{35}$

Moreover, in 1946 ASF began more active fundraising. The organisation hoped to fundraise one million dollars in order to wipe out war deficits and add to their endowment fund. ${ }^{36}$ This fundraising led to several new types of donations to the ASF, the majority of which were restricted to educational exchange. As there were many such funds, only a few will be discussed in detail. Additionally the donation types will be grouped thematically: firstly, group donations and fundraised donations; secondly, large single donations; thirdly, organisational grants; and fourthly, private bequests.

33 ASF 1944, 4-5.

34 ASF AR 1945, 6; Friis (1961), 61-62.

35 ASF AR 1944, 5-6; 1945, 6; 1947, 8-9; Friis (1961), 69. See also the correspondence from 1946 and 1947 between the Swedish Consulate in New York, the Swedish embassy in Washington, the Swedish Ministry for Foreign Affairs and the Sweden-America Foundation in E1:35, Sweden-America Foundation, Riksarkivet [National Archive of Sweden, Stockholm]. 
Table 1. Funds and grants of \$50,000 or more for educational exchange, 1945-1980

$\begin{array}{lllll}\text { Year Fund name (Donor origin) } & \text { Type } & \text { Amt (\$) Stipulation } \\ 1945 \text { King Haakon B-day (U) } & \text { G } & 50 \mathrm{k} & \text { Norwegians studying in U.S. } \\ 1955 \text { Haakon Styri (U) } & \text { B } & 160 \mathrm{k} & \text { Engineering between Norway and U.S. } \\ 1955 \text { Henrik Kauffman (C) } & \text { G,F } & 150 \mathrm{k} & \text { Between Denmark and U.S. } \\ 1956 \text { Princess Märtha (C) } & \text { G,F } & 80 \mathrm{k}^{* *} & \text { Between Norway and U.S. } \\ 1959 \text { Finnish Leaders (U) } & \text { OT } & 140 \mathrm{k} & \text { Finnish leaders to U.S. } \\ 1960 \text { Bernadotte (C) } & \text { F } & 50 \mathrm{k}^{* *} & \text { Between Sweden and U.S. } \\ 1962 \text { Alice and Corrin Strong (U) } & \text { G } & 50 \mathrm{k} & \text { Arts between Norway and U.S. } \\ 1964 \text { Thord-Gray (U) } & \text { B } & 2.6 \mathrm{~m} & \text { Between Sweden and U.S. } \\ 1965 \text { Thor Thors (C) } & \text { G,F,B,OT } & 100 \mathrm{k}^{*} & \text { Between Iceland and U.S. } \\ 1967 \text { Finnish Fund (C) } & \text { F } & 60 \mathrm{k}^{* *} & \text { Between Finland and U.S. } \\ 1967 \text { Martha and Jack K. McFall (U) } & \text { B } & 70 \mathrm{k}^{*} & \text { Between Finland and U.S. } \\ 1968 \text { George C. Marshall (S) } & \text { OT } & 1 \mathrm{~m} & \text { Americans studying in Denmark } \\ 1969 \text { Thanks to Scandinavia (C) } & \text { OT } & 75 \mathrm{k}^{*} & \text { Scandinavians to U.S. } \\ 1972 \text { Helen Lee and Emil Lassen (C) } & \text { O } & 175 \mathrm{k}^{* *} & \text { Between Denmark and U.S. } \\ 1973 \text { King Olav V 70th Birthday (U) } & \text { F } & 200 \mathrm{k}^{* *} & \text { Between Norway and U.S. } \\ 1975 \text { Icelandic Leaders (U) } & \text { OT } & 200 \mathrm{k} & \text { Icelandic leaders to U.S. } \\ 1977 \text { Mathilde Aas (U) } & \text { B } & 440 \mathrm{k} & \text { Norwegians studying in U.S. } \\ 1980 \text { Andrew and Norman Wigeland (U) B } & 2.5 \mathrm{~m} & \text { Norwegians studying in U.S. } \\ 1980 \text { Schaefer (S) } & \text { B } & 100 \mathrm{k} & \text { Unrestricted educational exchange }\end{array}$

Sources: ASF Annual Reports 1944-95, ASF “A Centennial Chronicle 1911-2011." Part 1-3.

Legendfordonororigin: $\mathrm{U}=$ UnitedStates, $\mathrm{S}=\mathrm{S}$ candinavia, $\mathrm{C}=$ Combination of AmericanandScandinavian

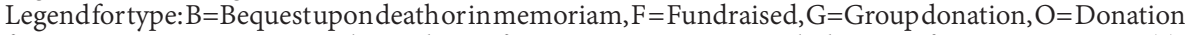
from organisation, $\mathrm{OT}=$ Time-limited grant from organisation, $\mathrm{P}=$ Single donation from privateperson(s). ${ }^{*}$ Amount is approximated due to missing annual reports or incomplete information.

${ }_{* *}^{*}$ Amount of fund after the initial fundraising period.

${ }^{* * *}$ As of 1974

Table 1 above shows funds created from donations of $\$ 50,000$ or more in 1945-1980. This table ends in 1980 as the ASF reformatted their annual reports after this time period, and there is less consistent information regarding the amounts, sources, and restrictions of donations. The selection shows that donations of $\$ 50,000$ or more were generally given to the ASF by a combination of Scandinavian and American sources. While donations received before 1945 followed pre-war logic and were restricted for use by American fellows, donations after 1945 were progressively oriented toward Scandinavians traveling to the United States or for equal exchange between a particular Scandinavian country and the United States. Less common were restrictions based on academic subject or educational level, though there were two grants particularly devoted to funding Finnish and Icelandic leaders, a special group of fellows traveling to the United States to explore the industrial and business communities. 
The first donations which boomed in this period are group donations and fundraised donations. There were a total of 6 such funds created in 1945-1973 beginning with King Haakon Birthday Fund. Ten years later, large group donations resulted in the creation of both the Henrik Kauffman Fund and the Crown Princess Märtha Friendship Fund. These donations were the first of many to be donated by a combination of Scandinavian and American sources, in this case Danes and Americans and Norwegians and Americans respectively. While the Kauffman Fund was made in honor of the then Danish Ambassador to the United States, Henrik Kauffman, the second fund was collected in memory of Crown Princess Märtha of Norway. ${ }^{37}$ Though these were considered group donations, they were left open for further donations which could be added to the principal, and therefore are closely related to fundraiser donations, the main difference being that these funds were initiated through outside sources instead of the ASF.

The period of strategic fundraising began in 1960 with the commemoration of the Bernadotte Fund. This was the first time in which the ASF initiated a campaign for fund development with a particular geographic focus, in this case for exchange between Sweden and the United States. The Bernadotte Fund was later followed by the Thor Thors Fund for two-way Icelandic exchange in 1965 and the Finnish Fund for two-way Finnish exchange in $1967 .{ }^{38}$ In keeping with a renewed focus on fundraising, the ASF also created the Corporate Giving Program in 1960 with the same premise as the Life Associates program from the 1920s. Though, instead of targeting private persons, this campaign targeted American businesses. There were three levels: Corporate donor ( $\$ 1,000$ or more), Corporate Sustainer ( $\$ 500-\$ 999)$, and Corporate Contributor (\$100-\$499). ${ }^{39}$ This proved to be a significant funding scheme for the organisation, generating $\$ 20,000$ to $\$ 80,000$ per year for unrestricted purposes into the $1990 \mathrm{~s}^{40}$ These contributions were used for administrative and other costs, so that the income interest from capital funds could be used primarily for creating scholarships.

The second donation type of single, large donations from private persons led to two of the most restricted donations in 1959. Two \$20,000 trust funds were donated by New York resident, Haakon Björnström Steffanson, the income to be used for Swedish graduate students to study in the United States, minus 5 per cent for administrative purposes. Candidates for these scholarships were to be nominated respectively by the Rector of Uppsala University and by the Sweden-America Foundation. ${ }^{41}$ In addition to these rather large donations, there were several private persons who donated smaller amounts, between $\$ 5,000$ and $\$ 15,000$, for various purposes. Unlike the Björnström Steffanson donations, however, they were not restricted to using only interest income, so they were generally utilised in the short-term instead of establishing permanent funds. This logic was a remnant of the pre-WWII period and

\footnotetext{
37 ASF AR 1955, 5; Friis (1961), 79, 81.

38 ASF AR 1965, 6; 1970, 7.

39 ASF AR 1960, 5.

40 “A Centennial Chronicle 1911-2011," Part 2. Special Issue of Scandinavian Review, Summer 2011, 50-51.

41 Friis (1961), 89.
} 
still remains as a small yet significant part of funding for academic exchange within the organisation.

Thirdly, in the late 1950s to mid-1970s, grants to the ASF from other organisations became increasingly common. These grants were generally given to the ASF for administration, to be used for a brief period. In 1959-1975, there were six such organisational grants, all time-limited in some fashion. The first of which was a large grant from the Ford Foundation in 1956 for Finnish leaders, followed later by a grant from the Independence Foundation in 1975 for Icelandic leaders. ${ }^{42}$ The only grant given from a state-run organisation was the George C. Marshall Memorial Fund established in 1968 through funds raised in Denmark, which will be discussed more in the next section. ${ }^{43}$

In 1970, the most unique of these organisational grants was given by the Henry L. and Grace Doherty Foundation, the original \$50,000 to be divided into three parts. $\$ 25,000$ was to be used within two years to bring four Danish Foreign Service officers studying at the graduate level to the United States. The grant even suggested that these fellows could be placed at the Woodrow Wilson School at Princeton University. In addition, $\$ 20,000$ would be used to create the Helen Lee and Emil Lassen Fellowship Fund, the income of which would underwrite fellowships between Denmark and the United States. It was also hoped by the Doherty Foundation that future donations could be made to this fund. The remaining $\$ 5,000$ was stipulated for administrative expenses. By 1974, through additional contributions by the Doherty Foundation and private persons, the Lassen Fund had grown to $\$ 175,000 .{ }^{44}$

The final category of donations is perhaps the largest and most important for the economic growth of the organisation. Private bequests in the form of estates, offered the largest sums of capital from which the ASF could utilise interest income. The first major bequest began with the creation of Haakon Styri Fund in 1955, made upon the death of Haakon Styri, an American engineer and former ASF fellow. ${ }^{45}$ Five years later ASF received word that they would be the beneficiary of the Winnifred ThordGray estate. ${ }^{46}$ The bequest would be made concrete in 1964, upon the death of Winnifred Thord-Gray and was the largest bequest received by the ASF up to that point, rivaled only by the bequest of the Wigeland estate in 1980 . The bequests amounted to approximately 2.6 million dollars each in securities and cash. ${ }^{47}$ Because of the enormity of the Thord-Gray bequest, a personal note is written in the annual report in 1960, thanking Winnifred Thord-Gray and her husband for their participation as long-time Life Associates of the foundation as well as their interest in international education and Swedish-American relations. ${ }^{48}$

In the midst of these increasingly varied donations, a significant tax code revision for American philanthropic organisations was passed into law in 1969, and the ASF

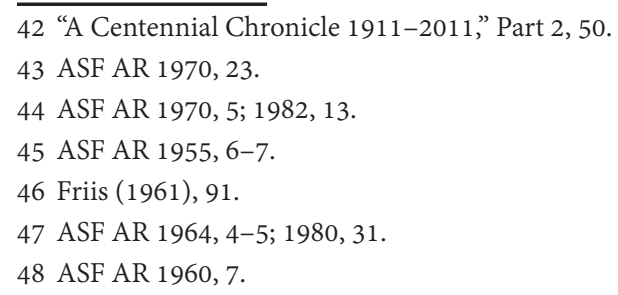


was required to re-register with Treasury Department to receive a tax ruling. On March 18, 1969, the ASF received news from the Internal Revenue Service (IRS) that it would be classified as a non-profit organisation under the section 501(c)(3) of the tax code and sub-classified as a "publicly supported institution," commonly referred to as a public charity. After this ruling, the ASF officially separated from its previous association as a private foundation. The organisation welcomed this news, as this new tax ruling offered up to a 50 per cent tax deduction for donors, while private foundations could only offer up to a 30 per cent deduction. ${ }^{49}$

As this section proves, the period of 1945-1995 was a period of substantial change for the organisation. Not only was the official classification of the ASF altered, but the size and character of donations changed significantly. While the preWWII period was marked by small donations for immediate use, this period saw the rise of large donations stipulated for perpetual investment. These led to an increase in the economic assets of the organisation. In 1941 the assets were \$390,000; by 1995 these assets had ballooned to 21 million dollars. ${ }^{50}$ Even when adjusted for inflation, this represents a 430 percent increase in total assets from 1941 to 1995. Additionally, there seem to be three characteristics to these donations which stand out. Donations were often given in memoriam or in response to a significant event in Scandinavian history and culture; bequeathed by those who had long-standing personal ties to the organisation; or given as grants through other organisations within the framework of shared goals and aims. Furthermore, these ties, whether personal, commemorative, or professional, dictated the purpose of the funds. In the case of the ASF, these restrictions were based on geography or time and, more seldom, based on academic subject or level.

\section{The changing flow of fellows}

This altered funding pattern and increase in assets is also clearly visible in the compositional change of fellowship holders from before and after 1945. In the period of 1912-1944, scholarship funding focused on American fellows, while in 1945-1995, exchange was extended to an increasing number of Scandinavian fellows. While 79 per cent of fellows travelled from the United States before the Second World War, from 1945 American fellows made up only 44 per cent of the population. ${ }^{51}$ This section will discuss how key donations accounted for much of the growth and compositional change with scholarship holders in 1945-1995. In order to understand the successive periods of change, these donations will be discussed in chronological order.

\footnotetext{
49 ASF AR 1970, 4.

50 ASF AR 1941, 12; 1995, 30.

51 Calculated from the 295 fellowships (234 American, 61 Scandinavian) awarded in 1912-1954 and the 3002 fellowships (1310 American, 1692 Scandinavian) in 1945-1995 as listed in the American-Scandinavian Foundation, Directory of Fellows 1912-1997 (New York: American-Scandinavian Foundation, 1998).
} 
Figure 2. Scandinavian and American fellows by exchange country, 1912-1995

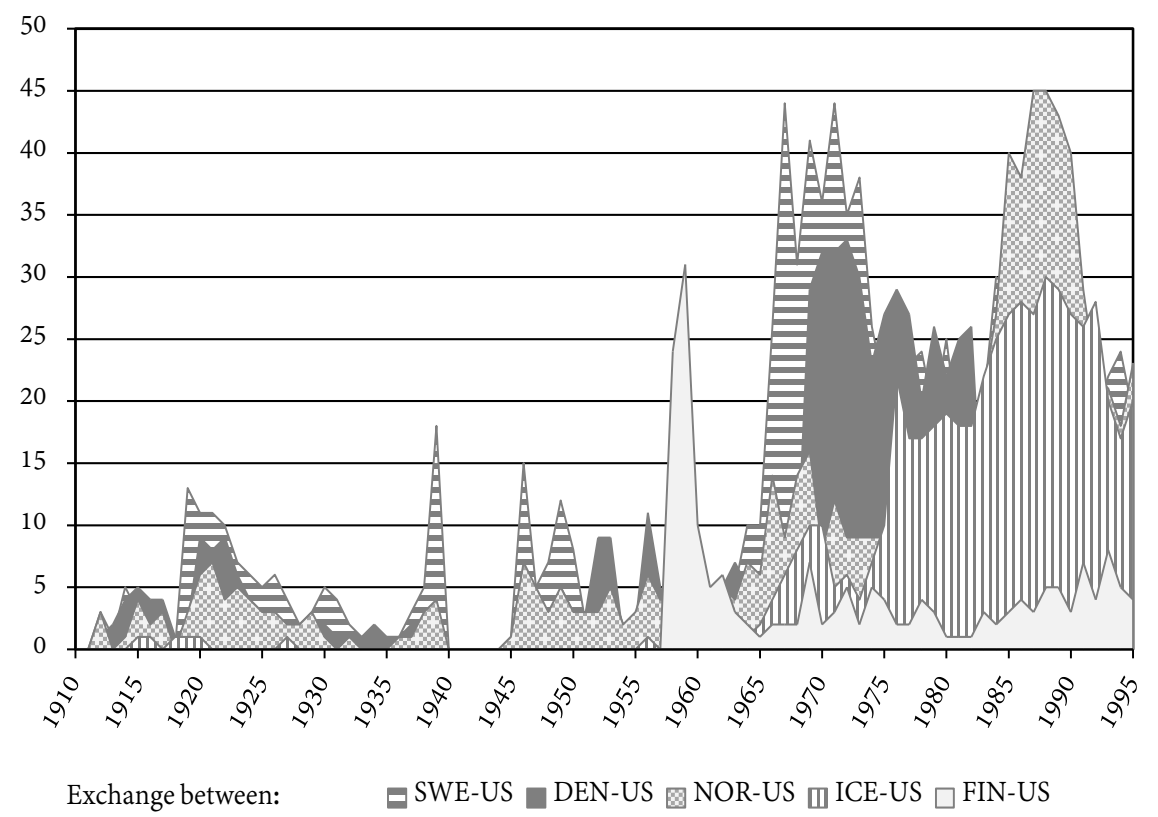

Sources: ASF Annual Reports 1912-95 and ASF Directory of Fellows 1912-97

As can be seen in Figure 2 above, there are five major peaks after the Second World War which strongly relate to specific exchange countries: the light gray Finland-US peak in 1958-1961; the horizontally striped Sweden-US peak from in 1967-1973; the dark gray Denmark-US peak in 1969-1982; the vertically striped Iceland-US block in 1973-1995; and the dotted Norway-US peak in 1982-1990. While Figure 1 showed the overall increase of Scandinavian scholars, this figure shows all fellows traveling between the United States and the particular Scandinavian countries, as most funds are stipulated for equal exchange between countries. When fellowships between each Scandinavian country and the United States are graphed at the same level, it is easier to see which country dominated in a certain era.

The change of fellow composition begins with the light gray peak of Finnish fellows in 1958-1961. This peak followed a significant event for the ASF, when the Finland-America Society became the fifth cooperating organisation in 1956. The event was quickly commemorated by the donation of $\$ 140,000$ by the Ford Foundation to begin an exchange program with Finland. The grant covered four years, 1957-1960, and stipulated that a total of 50 Finnish leaders in the fields of communications, creative and performing arts, and the legal and clerical professions be financed. Each leader was financed for a 60-day trip to the United States to meet American colleagues, make contacts, and "receive new impulses from American life and culture." 52 Though originally intended to support 50 Finnish leaders, the program eventually financed 74 leaders from 1958-1963. 
The second peak in 1967-1973 for Swedish-American exchange resulted from the creation of the Thord-Gray Memorial Fund. The sheer size of the 2.6 million dollar Thord-Gray bequest, received in 1964, was acknowledged by the ASF as "represent[ing] an opportunity of unprecedented proportions and point[ing] to a future pregnant with potential in helping to improve the quality of educational exchange and the level of understanding between Sweden and the United States." ${ }^{3}$ The first exchange was conducted in 1966, and for the next seven years, there was a strong domination in exchange between Sweden and the United States. From 1966-1995, this fund supported approximately 630 fellows, with 48 per cent of these fellows traveling from Sweden. In addition to Thord-Gray, there were several other funds which contributed to the height of this peak, including the John G. Bergquist Fund and the Bernadotte Fund which in later years provided less income, reducing the number of overall scholarships. Thord-Gray, on the other hand, supported an average of 22 fellows per year in 1967-1995.

The third peak in this time period was triggered by George C. Marshall Memorial Fund. This fund was established on the twentieth anniversary of the Marshall Plan by the George Marshall Board in Denmark and supported American fellows traveling to Denmark. Though originally intended for only five years, this fund was extended for an extra 10 years. ${ }^{54}$ In $1969-1982$, this fund supported 282 American fellows to Denmark, sending an average of 20 fellows per year. At the end of the program, this grant had underwritten nearly one million dollars in fellowships for Americans to Denmark. ${ }^{55}$ In the period of 1969-1982, 94 per cent of American fellows to Denmark were financed by the Marshall grant, as well as 55 per cent of all American fellows. An increase in American scholars during this period can also be seen in Figure 1.

The fourth peak, or rather block, represents fellowships for travel between Iceland and the United States. This is the longest block of scholars represented in the graph, extending from 1973-1995, though it is likely that this dominance continued for later years as well. The block consists primarily of fellows financed by the Thor Thors Fund. This fund is one of the most complex funds held by the ASF, and is made up of two parts. The original $\$ 25,000$ donation was given by the Rockefeller Brothers in 1967, but as it was considered a grant, it needed to be used within five years. This can be seen in the rise of Icelandic fellows from 1965-1970. The second part of the fund used large donations for investment, $\$ 50,000$ worth of the fund was donated through fundraising and another $\$ 50,000$ was donated to the ASF directly by Iceland's president in 1967. Much of the donation from the Icelandic president consisted of contributions from Icelandic industries and the government which had benefited from Marshall Plan aid. ${ }^{56}$ From the original $\$ 100,000$, more funds were constantly raised, so by 1985 this fund amounted to nearly $\$ 370,000 .{ }^{57}$ This long-term trend of exchange between Iceland and the US led to an impressive 18 per cent of the total postWWII population. Though, despite the fact that the Thor Thors fund was stipulated for two-way exchange, only 2 per cent of this population was American.

53 ASF AR 1964, 5; ASF AR 1966, 11.

54 ASF AR 1970, 23.

55 “A Centennial Chronicle 1911-2011," Part 3, 33.

56 “A Centennial Chronicle 1911-2011," Part 2, 47.

57 ASF AR 1985, 32. 
The fifth and final peak consists of Norwegian fellows throughout the 1980s. This peak was triggered by the bequest of the Wigeland estate in 1980, which became the Andrew E and G. Norman Wigeland Memorial Fund. From 1980-1995, this fund provided scholarships for over 300 Norwegian fellows. At its peak in 1985-1990, the interest income allowed for the funding of 30 fellows per year. 88 per cent of all fellows traveling from Norway to the United States after 1980 were financed by this fund. In addition, the Wigeland fund was established within a few years of the Mathilde Aas fund, also designated for Norwegian fellows, which only added height to this peak. These two restricted funds also allowed for the ASF to use funds donated for exchange between Norway and the US on scholarships for American fellows. So despite the size of the Wigeland and Mathilde Aas funds, this did not create a large disparity in the two-way exchange between Norway and the US. In fact, 40 per cent of the Norway-US fellows consisted of Americans after 1980.

As can be evidenced from the examples, there are two major elements which cause peaks for fellows from certain countries within the ASF: the size of a donation and the type of restriction. In the case of the peaks discussed above, large funds restricted by geography or by time tend to cause the biggest compositional shifts. What is also interesting is that there was a much more equal distribution of fellows in the postWWII years, with the exception of Finland and Iceland. The majority of scholarships continued to be dominated by the three countries which established cooperating organisations in the 1910s: 22 per cent of scholars traveled between Denmark and the US, 23 per cent between Norway and the US, and 31 per cent between Sweden and the US. While Finland-US exchange continued to comprise only 6 per cent of the population, Iceland-US exchange constituted 18 per cent of the population.

\section{Conclusions}

The financial history of the American-Scandinavian Foundation analyzed in this article is clearly divided into two eras, with the Second World War as the central watershed. The first period of 1912-1944, began with the ASF orienting itself within the organisational environment in the United States while striving to make contacts with Americans with personal ties to Scandinavia as well as reaching out and establishing cooperating organisations in Scandinavia. The ASF was able to maintain a low, but nearly constant level of scholars before the Second World War, 79 per cent of which were American. These scholars were mainly financed through direct donations from individuals with close personal ties to Scandinavia and the organisation. In some cases, such as the poet Hillyer mentioned in this article, the ASF seems to have served as a mediator between Hillyer and ASF trustee, Henry Goddard Leach. In times of disruption, such as the late 1920s and 1930s, the ASF also received financial support from large private foundations such as the Rockefeller Foundation and the Carnegie Corporation in combination with private contributions. Compared to the post-WWII era, however, the numbers of fellowships remained low.

The period 1945-1995 marked a changed logic in both organisational economy and scholarship financing. From the first bequest of $\$ 50,000$ in 1945 , large donations stipulated for educational exchange steadily flowed into the organisation. An important difference from the previous period was the increasing number of large bequests and donations used to form perpetual funds. These funds financially stabilised the ASF, which made long-term planning possible. The surplus of such funds also al- 
lowed the organisation to finance larger numbers of scholars. While only 302 fellows traveled before 1945, 3002 fellows, or 91 per cent of the population investigated in this article, traveled in 1945-1995.

Another important shift from the pre-WWII era to the post-WWII era is the larger variety in the geographic origin of donations. Before 1945, the donors were almost exclusively from the United States, but during the post-WWII period a number of donations were made from mixed or purely Scandinavian sources. Additionally, the organisation widened its scope to include Iceland in 1940 and Finland in 1956. The group of fellows in the post-WWII period was thus not only substantially larger, but there was much more variety in both the origins and destinations of the scholars. While the majority of fellows before the Second World War were American, the post-WWII period saw a rise in fellows from all parts of Scandinavia. The cooperating organisations in Scandinavia continued to play an important role in recommending and administrating ASF-financed Scandinavian fellows in this period, which maintained the international cooperation fostered in the pre-WWII period.

The most notable block of increased interchange was due to the Thor Thors fund for exchange between Iceland and the United States, which funded large amounts of Icelandic fellows for study in the United States from 1965. As shown in the last part of this article there is an obvious relationship between the large donations made to the ASF and the geographic area of exchange at a certain point in history. This was exemplified with the large donations made for Sweden-US exchange and for Norwegians to the US, both funded from large bequests of over 2.5 million dollars. It was also shown through the short bursts of scholarships created by organisational grants from the Ford Foundation for Finland and for Americans to Denmark from the Danish government.

Although the ASF shows a rising number of scholarship holders, the composition of this group regarding origin has not been constant. Instead, the present study shows that the geographical origin has fluctuated as a direct result of donations made to the organisation. On a more general level, this means that some of the fluctuations and long-term changes in international exchange could be explained through examining how it is financed. In relation to previous research, in particular Melldahl's report on the Sweden-America Foundation, this article provides fundamental insight into the financial basis of ASF exchange activities in particular and of American-Scandinavian exchange in general, which has not previously been investigated. This article shows that although the donations to the ASF were restricted, they were primarily restricted by country rather than academic field. Therefore, funding generally only dictated the amount of scholarships for a given country, not the academic composition of scholarship holders. This means that the available funding through donations and the rules attached to these donations were additional factors which should be considered when explaining the number, origin and in some cases academic fields of scholarship holders as presented by Melldahl.

This small investigation does, however, need further contextualisation in at least two regards. Firstly, further investigations should be conducted regarding the internal economic life of philanthropic organisations working in international exchange as well as regarding the relationship between donations and organisational operations in general. How is the work of other philanthropic organisations affected by funding obtained through donors and beneficiaries? Secondly, the relative size of 
Scandinavian-American exchange through the ASF should be investigated. Has the organisation historically been a large actor in this arena? Does it represent a microcosm of a much larger Scandinavian-American organisational network for international exchange? Despite the need for further clarification, the present article does show that educational exchange financed by the ASF has grown and diversified from 1912 to 1995, and much of this growth and diversification can be explained by the character of the donations made to the organisation. 


\section{References}

\section{Archival sources}

Riksarkivet, Stockholm [Swedish National Archives]

Sverige-Amerika stiftelsen [Sweden-America Foundation].

\section{Printed sources and literature}

"A Centennial Chronicle 1911-2011" Part 1. Special issue of Scandinavian Review. Spring 2011.

“A Centennial Chronicle 1911-2011" Part 2. Special issue of Scandinavian Review. Summer 2011.

"A Centennial Chronicle 1911-2011" Part 3. Special issue of Scandinavian Review. Fall 2011.

American-Scandinavian Foundation. Directory of Fellows 1912-1997. New York: American-Scandinavian Foundation, 1998.

Blanck, Dag. "Scholars across the Seas: The American-Scandinavian Foundation and the Sweden-America Foundation in the Transatlantic Exchange of Knowledge." American Studies in Scandinavia 40 no. 1-2 (2008), 110-25.

Bureau of Labor Statistics. "Consumer Price Index." United States Department of Labor. http://www.bls.gov/cpi/.

Curti, Merle. American Philanthropy Abroad. New Brunswick: Rutgers University Press, 1963.

Engwall, Lars. "Stiftelsernas fördelning av forskningsmedel." In Femtio år av forskningsfinansiering: Jan Wallanders och Tom Hedelius stiftelse, Tore Browaldhs stiftelse 1961-2011, edited by Bo Damberg and Jonas Rehnberg, 46-51. Stockholm: Informationsförlaget, 2011.

Friis, Erik J. The American-Scandinavian Foundation 1910-1960: A Brief History. New York: The American-Scandinavian Foundation, 1961.

Frumkin, Peter. "American Foundations and Overseas Funding: New Challenges in the Era of Globalization." In Globalization, Philanthropy, and Civil Society: Toward a New Political Culture in the Twenty-First Century, edited by Soma Hewa and Darwin H. Stapleton, 99-115. London: Springer Science, 2005.

Gemelli, Guiliana, ed. American Foundations and Large-Scale Research: Construction and Transfer of Knowledge. Bologna: CLUEB, 2001.

Helgesson, Christian. "Donationer i Sverige, filantropi i USA." In Sista fracken inga fickor har: Filantropi och ekonomisk tillväxt, edited by Pontus Braunerhjelm and Göran Skogh, 141-61. Stockholm: SNS Förlag, 2004.

Kriege, John and Helke Rausch, eds. American Foundations and the Coproduction of World Order in the Twentieth Century. Göttingen: Vandehoeck \& Ruprecht, 2012.

Ljungström, Olof. Ämnessprängarna: Karolinska Institutet och Rockefeller Foundation 1930-1945. Stockholm: Karolinska Institutet University Press, 2010.

Melldahl, Andreas. Västerled tur och retur del 1: Utbildning och ekonomi: En ekonomiskhistorisk studie av Sverige-Amerika Stiftelsens stipendieverksamhet 19192006. Uppsala: SEC Research Reports no. 44, 2008.

Nielsen, Waldemar A. The Big Foundations. New York: Columbia University Press, 1972 . 
Nielsen, Waldemar A. Inside American Philanthropy: The Dramas of Donorship. Norman: University of Oklahoma, 1996.

Sjögren, Hans. "Svenska stiftelser." In Sista fracken inga fickor har: Filantropi och ekonomisk tillväxt, edited by Pontus Braunerhjelm and Göran Skogh, 35-54. Stockholm: SNS Förlag, 2004. 